\title{
RESEARCH
}

Open Access

\section{Bradymonabacteria, a novel bacterial predator group with versatile survival strategies in saline environments}

Da-Shuai Mu ${ }^{1,2}$, Shuo Wang ${ }^{2}$, Qi-Yun Liang ${ }^{2}$, Zhao-Zhong Du², Renmao Tian ${ }^{3}$, Yang Ouyang ${ }^{3}$, Xin-Peng Wang ${ }^{2}$, Aifen Zhou ${ }^{3}$, Ya Gong ${ }^{1,2}$, Guan-Jun Chen ${ }^{1,2}$, Joy Van Nostrand ${ }^{3}$, Yunfeng Yang ${ }^{4}$, Jizhong Z Zou ${ }^{3,4}$ and Zong-Jun $\mathrm{Du}^{1,2^{*}}$

\begin{abstract}
Background: Bacterial predation is an important selective force in microbial community structure and dynamics. However, only a limited number of predatory bacteria have been reported, and their predatory strategies and evolutionary adaptations remain elusive. We recently isolated a novel group of bacterial predators, Bradymonabacteria, representative of the novel order Bradymonadales in $\delta$-Proteobacteria. Compared with those of other bacterial predators (e.g., Myxococcales and Bdellovibrionales), the predatory and living strategies of Bradymonadales are still largely unknown.

Results: Based on individual coculture of Bradymonabacteria with 281 prey bacteria, Bradymonabacteria preyed on diverse bacteria but had a high preference for Bacteroidetes. Genomic analysis of 13 recently sequenced Bradymonabacteria indicated that these bacteria had conspicuous metabolic deficiencies, but they could synthesize many polymers, such as polyphosphate and polyhydroxyalkanoates. Dual transcriptome analysis of cocultures of Bradymonabacteria and prey suggested a potential contact-dependent predation mechanism. Comparative genomic analysis with 24 other bacterial predators indicated that Bradymonabacteria had different predatory and living strategies. Furthermore, we identified Bradymonadales from 1552 publicly available $16 \mathrm{~S}$ rRNA amplicon sequencing samples, indicating that Bradymonadales was widely distributed and highly abundant in saline environments. Phylogenetic analysis showed that there may be six subgroups in this order; each subgroup occupied a different habitat.

Conclusions: Bradymonabacteria have unique living strategies that are transitional between the "obligate" and the socalled facultative predators. Thus, we propose a framework to categorize the current bacterial predators into 3 groups: (i) obligate predators (completely prey-dependent), (ii) facultative predators (facultatively prey-dependent), and (iii) opportunistic predators (prey-independent). Our findings provide an ecological and evolutionary framework for Bradymonadales and highlight their potential ecological roles in saline environments.
\end{abstract}

Keywords: Bacterial predator, Bradymonadales, Metabolic deficiencies, Comparative genomic analysis, Biogeographic analysis

\footnotetext{
* Correspondence: duzongjun@sdu.edu.cn

${ }^{1}$ State Key Laboratory of Microbial Technology, Institute of Microbial

Technology, Shandong University, No. 72, Jimo Binhai Road, Jimo, Qingdao

266237, China

${ }^{2}$ Marine College, Shandong University, Weihai 264209, China

Full list of author information is available at the end of the article
}

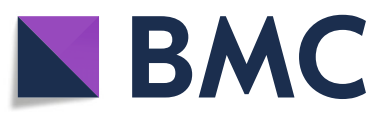

(c) The Author(s). 2020 Open Access This article is licensed under a Creative Commons Attribution 4.0 International License, which permits use, sharing, adaptation, distribution and reproduction in any medium or format, as long as you give appropriate credit to the original author(s) and the source, provide a link to the Creative Commons licence, and indicate if changes were made. The images or other third party material in this article are included in the article's Creative Commons licence, unless indicated otherwise in a credit line to the material. If material is not included in the article's Creative Commons licence and your intended use is not permitted by statutory regulation or exceeds the permitted use, you will need to obtain permission directly from the copyright holder. To view a copy of this licence, visit http://creativecommons.org/licenses/by/4.0/. The Creative Commons Public Domain Dedication waiver (http://creativecommons.org/publicdomain/zero/1.0/) applies to the data made available in this article, unless otherwise stated in a credit line to the data. 


\section{Background}

Bacterial predators have been proposed as an indispensable selective force in bacterial communities [1-4]. Predation by bacteria can release nutrients [5] and affect biogeochemical cycling. In contrast to phages, bacterial predators do not need to be present in high concentrations to drive significant bacterial mortality in the environment [6, 7]. In addition, bacterial predators have higher prey-killing efficiency in low-nutrient medium than phages [8]. However, these studies have mostly been based on Bdellovibrio and like organisms (BALOs), and little is known of the ecological roles of other bacterial predators.

Predatory bacteria are classified into two categories, obligate or facultative predators, based on their preyindependent or prey-dependent living strategies [9]. Obligate predators include several genera collectively known as BALOs [10]. These predatory bacteria can attack their prey by penetrating the cell wall [11], dwelling in the periplasm, and then killing their host [12]. Therefore, their lifestyle depends on the presence of their prey in the natural environment, and BALOs lose viability within several hours if the prey is not available [8,13, 14]. Facultative predators also include several genera [9], such as Myxococcus, Lysobacter, and Herpetosiphon [15]. These predators kill their prey by secreting antimicrobial substances into the surrounding environment $[9,16]$. In general, the socalled facultative predators have been considered to be those that can be maintained as pure bacterial cultures and be free living without their prey in natural environments. However, due to the lack of additional types of predators, no assessment could be made with respect to how dependent they were on their prey. Furthermore, whether there is a transitional type between obligate and so-called facultative predators is unclear.

Bradymonabacteria are representative of the novel order Bradymonadales, which are phylogenetically located in the $\delta$-Proteobacteria [17]. The first type species of Bradymonadales, Bradymonas sediminis $\mathrm{FA} 350^{\mathrm{T}}$, was isolated in 2015 [17]. To date, 9 strains within the Bradymonadales have been isolated and found to belong to 7 candidate novel species; these Bradymonabacteria are bacterial predators [18]. Interestingly, the phylum Proteobacteria contains three orders of predatory bacteria. Among them, Myxococcales and Bradymonadales belong to $\delta$-Proteobacteria, while Bdellovibrionales were classified as Oligoflexia in 2017 [19]. Myxococcales and Bdellovibrionales are so-called facultative and obligate predators, respectively. Additionally, they have different distribution patterns in the environment. Myxococcales are mainly found in soil and sediment niches [20,21], while Bdellovibrionales are aquatic. However, how Bradymonadales adapt to predatory lifestyles and whether they have specific living strategies or ecological importance remain largely unknown.
Here, we analyzed the predation range of Bradymonadales on diverse bacteria and their predatory morphological and physiological characteristics. By using comparative genomic analysis of Bradymonadales and other predatory bacteria, we revealed the genetic and metabolic potential of this group. To assess the diversity and frequency of occurrence of the various ribotypes of known predators (Bradymonadales, Myxococcales, and Bdellovibrionales) on a global scale, we surveyed published 16S rRNA gene amplicon datasets from a number of ecosystems representing a broad range of geographic locations, climatic zones, and salinities. Our study provides an ecological and evolutionary framework for Bradymonadales and highlights their potential ecological roles in predation.

\section{Results}

Bradymonabacteria are efficient predators of diverse prey bacteria

In total, 9 strains of bacteria in the novel order Bradymonadales were isolated using the enrichment culture method [22]. Among these strains, eight strains were isolated from costal sediment sampled in Weihai, China, while strain YN101 was isolated from a Gaodao saltern $\left(36^{\circ} 54^{\prime} \mathrm{N}, 122^{\circ} 14^{\prime} \mathrm{E}\right)$ in Weihai, China. Strains FA350 $[17,18]$ and $\mathrm{B} 210^{\mathrm{T}}[23]$ are the two type strains for different genera of Bradymonadales. Both these type strains were used to investigate the predator-prey range of Bradymonabacteria. A total of 281 isolated bacteria were cocultured with Bradymonabacteria FA350 ${ }^{\mathrm{T}}[17,18]$ or B210 ${ }^{\mathrm{T}}$ [23] as lawns in individual Petri dishes (Fig. 1a, Table S1). Zones of predation were measured (Fig. 1b), and the results showed that the Bradymonabacteria preyed on diverse bacteria but showed a strong preference for Bacteroidetes ( $90 \%$ of tested bacteria could be preyed on) and Proteobacteria (71\% of tested bacteria could be preyed on) (Fig. 1c). Predation on bacteria in the orders Flavobacteriales, Caulobacterales, Propionibacteriales, and Pseudomonadales was broadly distributed, with a mean predation percentage greater than 90\%, while predation of Micrococcales and Enterobacteriales was less efficient.

Transmission electron microscopy (TEM) and scanning electron microscopy (SEM) analyses were performed to understand the mechanism of predation of strain FA350 ${ }^{\mathrm{T}}$ on the subcellular level. Lysis of the prey cells (Fig. 2a) was detected near strain FA350 ${ }^{\mathrm{T}}$ in both the TEM and SEM analyses (Fig. 2). Strain FA350 ${ }^{\mathrm{T}}$ was found to have pili (Fig. 2b, g) and outer membrane vesicle (OMV)-like structures (Fig. 2d, e, f, h). In addition, FA350 ${ }^{\mathrm{T}}$ cells contained intracellular particles with low electron density (Fig. 2b, c, d, f), which were shown to contain polyhydroxyalkanoates (PHAs) by Nile blue A staining. FA $350^{\mathrm{T}}$ cells also contained several electron-dense (black) spots (Fig. 

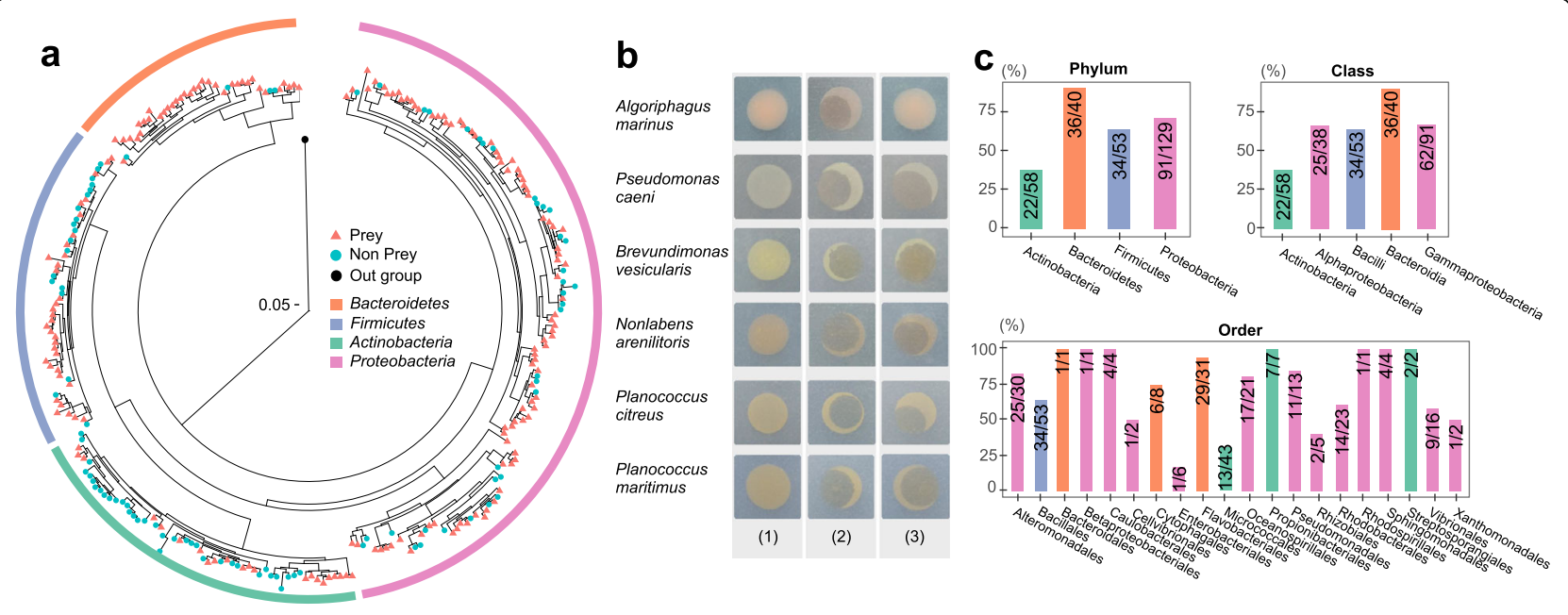

Fig. 1 Predation assays for potential prey organisms. a A total of 281 organisms were selected to test predation by two type strains of Bradymonadales. The phylogenetic tree was analyzed for the tested organisms. Red dots on the phylogenetic tree indicate that an organism could be preyed upon by either Bradymonas sediminis $\mathrm{FA} 350^{\top}$ or Lujinxingia litoralis B210 ${ }^{\top}$. Green dots indicate that the organism could not be preyed upon by either tested predator. Detailed information about the organisms on the tree is shown in Table S1. $\mathbf{b}$ The predation phenotype of Bradymonas sediminis FA350 ${ }^{\top}$ or Lujinxingia litoralis B210 ${ }^{\top}$ on prey. The numbers 1 to 3 indicate pure culture of different prey, mixed culture of Bradymonas sediminis $F A 350^{\top}$ and prey, and mixed culture of Lujinxingia litoralis B210 ${ }^{\top}$ and prey, respectively. $\mathbf{c}$ The percentage of organisms that could be preyed upon is shown in the bar chart

2b, c, d, f), which indicated the presence of intracellular polyphosphate granules [24]. Both of these particle types significantly accumulated during predation (Fig. 2).

\section{Bradymonabacteria are polyauxotrophs}

To explore the metabolic capabilities and predation mechanism of this novel group, we analyzed 13 genomes of Bradymonadales (9 high-quality genomes sequenced from cultured strains and 4 reconstructed from published studies [25]). The genome size of Bradymonabacteria ranged from 5.0 to $8.0 \mathrm{Mb}$ (Fig. S1a). Average nucleotide identity (ANI) analysis of the 9 cultured strains of Bradymonadales revealed 7 different species [26] (Fig. S1b). Other general features of the genomes are described in the Supplementary Materials (Supplementary Materials Results and Fig. S1a).

Almost all strains (except FA350 ${ }^{\mathrm{T}}$ ) possessed a minimal pentose phosphate pathway, which lacked key steps for the synthesis of ribose 5-phosphate (Fig. 3, Table S2) [27]. Most of the bradymonabacterial genomes lacked key enzymes for pyrimidine synthesis, such as aspartate carbamoyltransferase, which catalyzes the first step in the pyrimidine biosynthetic pathway. All genomes lacked the complete purine de novo pathway; they were missing the phosphoribosylaminoimidazole carboxylase catalytic subunit or even the whole pathway.

In addition to this auxotrophy in the synthesis of pentose and nucleotides, all the genomes lacked complete pathways for the synthesis of many amino acids, such as serine, methionine, valine, leucine, isoleucine, histidine, tryptophan, tyrosine, and phenylalanine (Fig. 3). For example, all the genomes encoded a potential D-3phosphoglycerate dehydrogenase for the conversion of glycerate-3P into 3-phosphonooxypyruvate for aminoacid synthesis (Fig. 3). However, in all members of Bradymonabacteria, this pathway appeared to be blocked at the subsequent step because of the absence of phosphoserine aminotransferase, although Bradymonabacteria could continue with subsequent pathways to complete the biosynthesis of cysteine and glycine. Additionally, many cofactors and vitamins that promote bacterial growth [22], such as biotin, thiamin, ubiquinone, $\mathrm{VB}_{12}$, and $\mathrm{VB}_{6}$, could not be synthesized by the de novo pathway in almost all the genomes. Notably, all the genomes had an incomplete pathway for type II fatty acid biosynthesis, lacking the key enzymes 3-oxoacyl-[acyl-carrierprotein] synthase I/II (FabB/F) and enoyl-[acyl-carrierprotein] reductase $(\mathrm{FabI} / \mathrm{L})$.

\section{Dual transcriptome analysis of the potential predation mechanism of Bradymonabacteria}

To further determine the genes involved in predation, we performed dual transcriptome analysis of Bradymonas sediminis $\mathrm{FA} 350^{\mathrm{T}}$ with and without preying on Algoriphagus marinus am2 (Fig. S2). As with obligate predators, one way that Bradymonabacteria kill their prey bacteria is likely by using contact-dependent mechanisms. Here, the bradymonabacterial genomes possessed complete type IV pili (T4P) (Fig. 3), and the attached areas showed more type IV pili than the unattached areas (SEM, Fig. 2g, h). The dualtranscriptome analysis showed that genes encoding the type IV pili twitching motility protein PilT (DN745_17255) were 

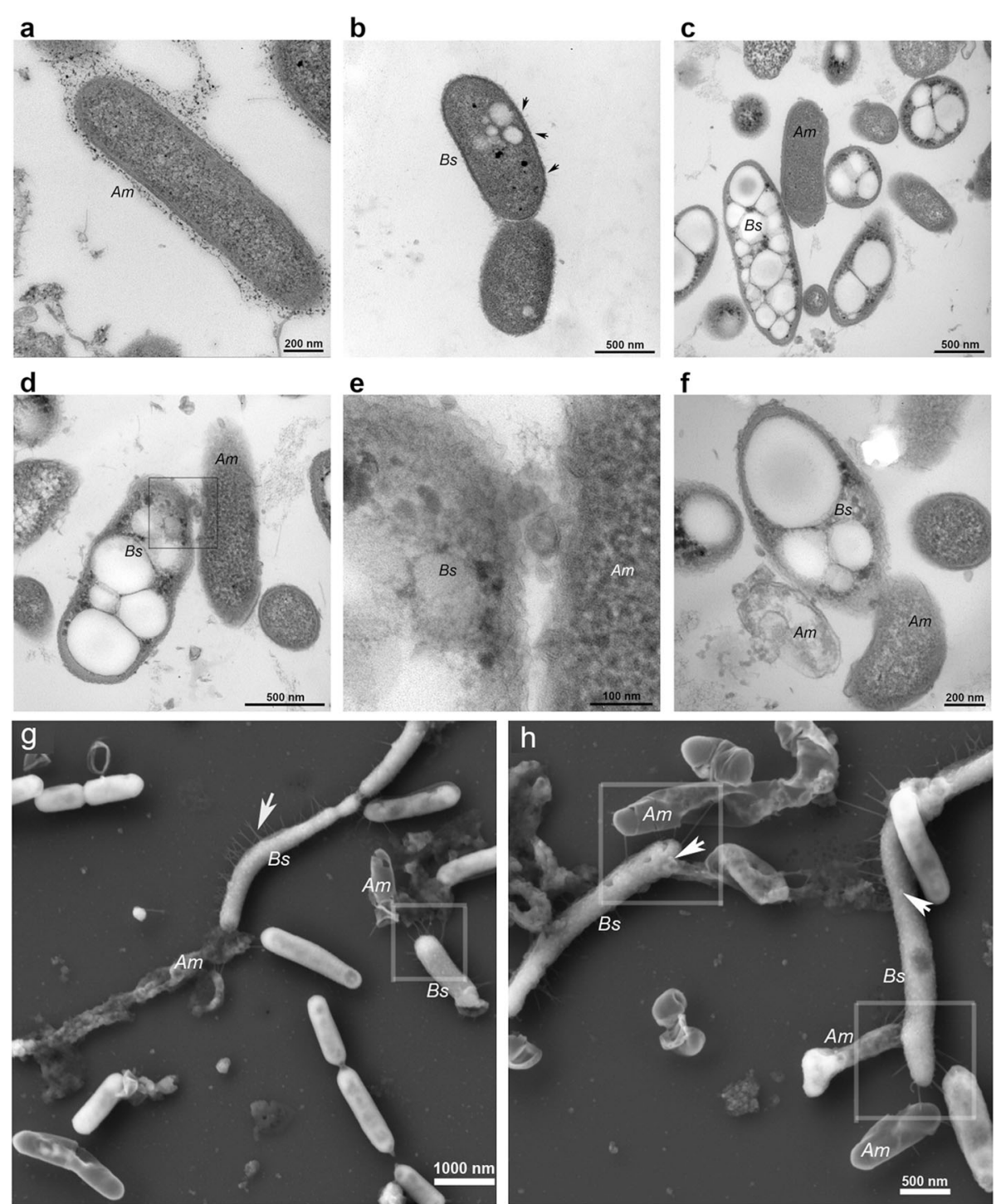

Fig. 2 TEM and SEM micrographs of Bradymonas sediminis FA350 (predator) and Algoriphagus marinus am2 (prey). We selected a prey, Algoriphagus marinus am2, which was smaller than the predator $\mathrm{FA}_{350}{ }^{\top}$. a The free-living prey Algoriphagus marinus am2 (Am) in pure culture. Bar $=200 \mathrm{~nm}$. $\mathbf{b}$ The free-living predator Bradymonas sediminis $F A 350^{\top}(B s)$ in pure culture. The white globose granules in the Bs cell indicate PHA accumulation, and the black arrows indicate type IV pili. Bar $=500 \mathrm{~nm}$. c Bradymonas sediminis FA350 (Bs) cells cocultured with Algoriphagus marinus am2 (Am) prey cells. The white globose granules in the cell indicate PHA accumulation, and the electron-dense (black) intracellular granules indicate polyphosphate. Bar = $500 \mathrm{~nm}$. d Bradymonas sediminis FA350 (Bs) cell attached to an Algoriphagus marinus am2 (Am) prey cell with OMV-like structures (shown in box area). Bar $=500 \mathrm{~nm}$. e Enlargement of the boxed area in figure (d). Bar $=100 \mathrm{~nm}$. f Bradymonas sediminis FA350 ${ }^{\top}$ (Bs) cell attached to an emptied and dead Algoriphagus marinus am2 (Am) prey cell. Bar $=200 \mathrm{~nm}$. g SEM analysis of Bradymonas sediminis FA350 ${ }^{\top}$ (Bs) cells cocultured with Algoriphagus marines am2 (Am) prey cells. The white arrow indicates type IV pili, and the boxed area indicates Bs contact with the emptied Am with type IV pili. Bar $=1000$ $\mathrm{nm}$. h SEM analysis of Bradymonas sediminis $\mathrm{FA} 350^{\top}(B s)$ cells attached to an Algoriphagus marinus am2 (Am) prey cell with type IV pili (shown in boxed area). The white arrows indicate the OMV-like structures. Bar $=500 \mathrm{~nm}$

significantly upregulated during predation (Fig. S3), suggesting that these genes may be involved in predation. Bradymonabacteria also had T4b pilins showing homology to those in Bdellovibrio bacteriovorus HD100, in which T4b pilins are necessary for predation $[28,29]$ (Fig. S4), so T4b pilins may also participate in regulating predation in Bradymonabacteria. In addition, this group of bacteria had type II and type III secretion systems (the YscRSTUV proteins that form a membrane-embedded complex known as the "export apparatus" [30]). The dual-transcriptome analysis also supported the prediction that genes encoding the type III secretion system inner-membrane protein complex (DN745_01900, DN745_10315, DN745_17280, DN745_03325, and DN745_ 00480) were significantly upregulated during predation (Fig. S3), implying that these genes may also be involved in predation. 


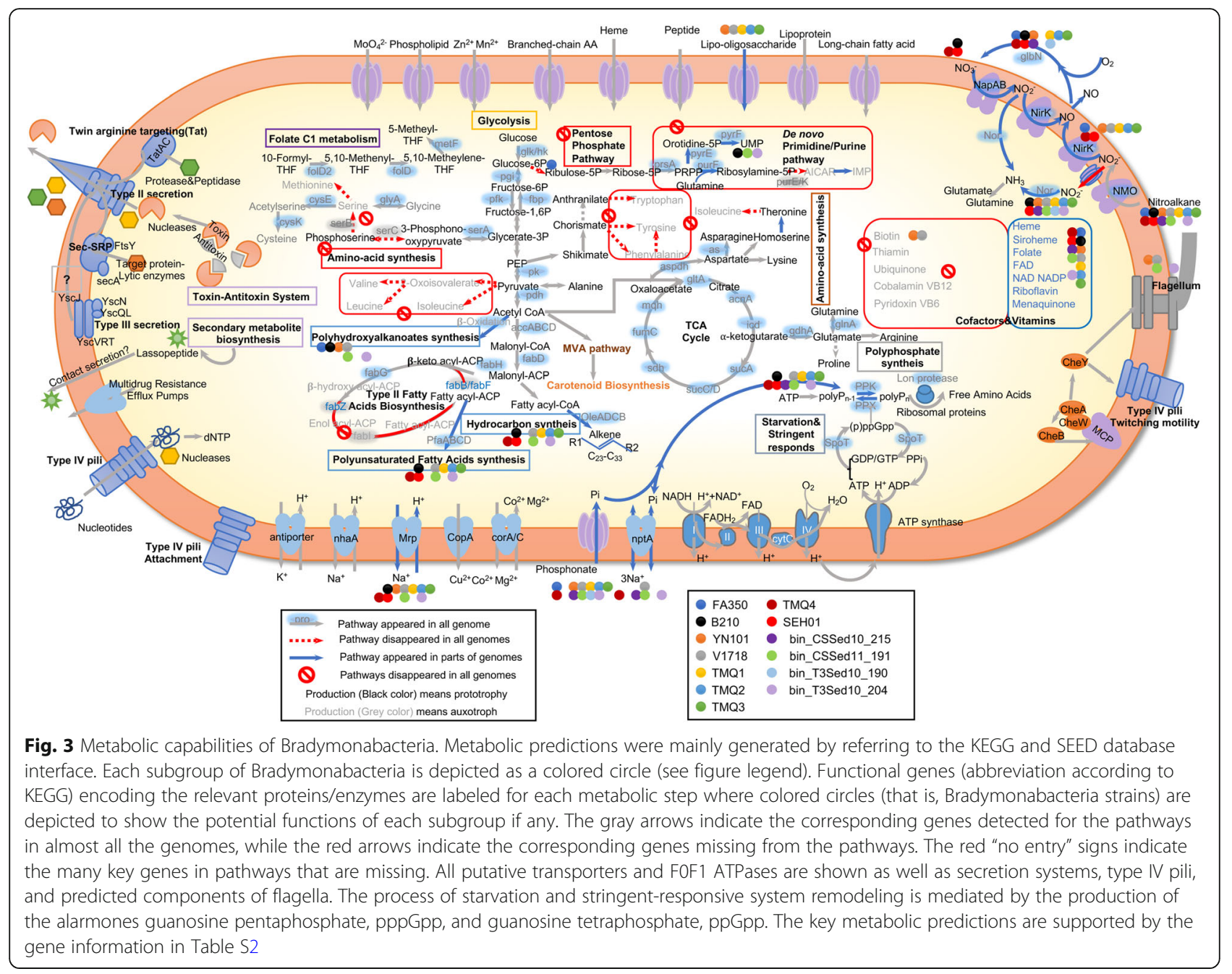

Another way that Bradymonabacteria kill their prey bacteria is likely by secreting antimicrobial substances into the surrounding environment. As in most facultative bacterial predators, a few potential antimicrobial clusters for secondary metabolite synthesis, such as Lasso peptide [31], were identified in almost all genomes of Bradymonabacteria (Fig. 3). Genes involved in outer membrane vesicle (OMV) biosynthesis were also detected in most genomes, such as ompA (cell envelope biogenesis protein), envC (Murein hydrolase activator), and tolR (envelope stability) [32]. Vesicle membranerelated genes (DN745_03865, DN745_02930, and DN745_07125) were significantly upregulated during predation (Table S4, Fig. S3). However, the fermentation supernatant of Bradymonabacteria showed no antibacterial activity.

\section{Bradymonabacteria are novel predators different from the so-called obligate or facultative predators}

Comparative genomic analysis with other bacterial predators was performed to explore whether Bradymonabacteria have a unique living strategy. Two-way cluster analysis showed that bradymonabacterial genomes contained features different from those of either obligate or facultative predators, which were phylogenetically located in a different branch (Fig. 4). The specific multiple metabolic deficiencies of Bradymonabacteria had some similarities to those of most obligate predators. For example, both Bradymonabacteria and obligate predators possessed a minimal pentose phosphate pathway, lacked key enzymes for pyrimidine synthesis, and lacked complete pathways for the synthesis of many amino acids, cofactors, and vitamins (Fig. 4). However, Bradymonabacteria with multiple auxotrophies could grow on common media (such as marine agar medium), though at a low growth rate [33], unlike obligate predators.

Unlike most obligate predators, the polyphosphate accumulation pathway, containing a pair of genes (polyphosphate kinase and exopolyphosphatase) associated with both polyphosphate formation and degradation [34], was present in most Bradymonabacteria (Fig. 4). Polyphosphate accumulation was also detected in FA350 ${ }^{T}$ cells during predation (Fig. 2). In contrast to most of the other 


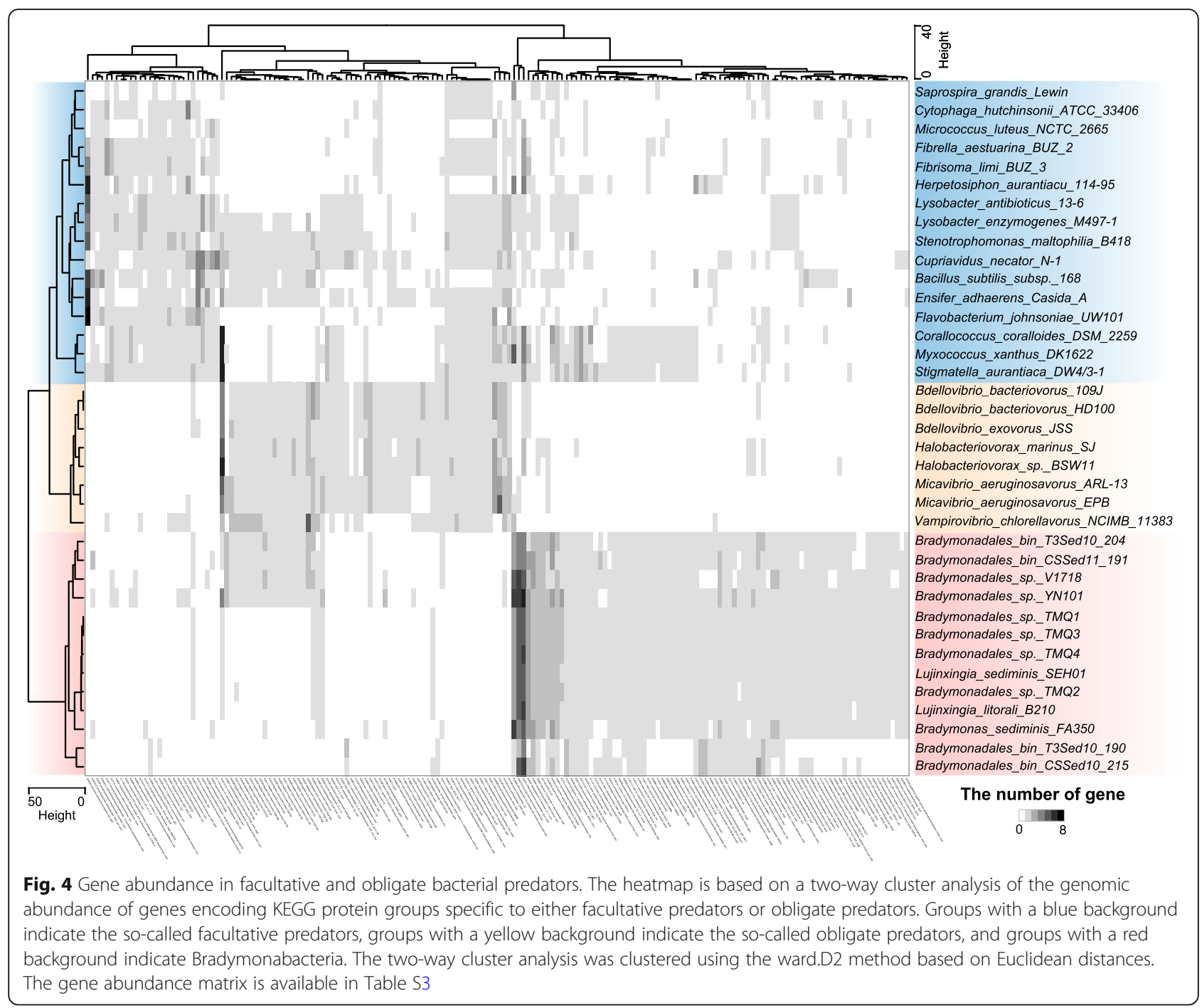

predator genomes, potential PHA synthesis from $\beta$ oxidation of fatty acids [35] was observed in most bradymonabacterial genomes (Fig. 3). In the present study, TEM analysis showed that strain FA350 ${ }^{\mathrm{T}}$ could significantly accumulate PHAs during predation observed in coculture with pure culture (Fig. 2). Despite their incomplete fatty acid biosynthetic pathway, all Bradymonabacteria had a high copy number of long-chain fatty acid transporters (fadL) compared to those of other predators, allowing them to gather fatty acids from the environment (Fig. 4). In addition, genes associated with alkane synthesis, which is important for maintaining cell membrane integrity and adapting to cold environments [36], were present in most genomes of Bradymonabacteria (Figs. 3 and 4). Thus, we proposed that Bradymonabacteria could be categorized as novel predators different from so-called obligate or facultative predators (Table 1).

\section{Bradymonadales are mainly distributed in saline environments with high diversity}

To evaluate the global prevalence of the Bradymonadales order, we surveyed recently published 16S rRNA gene amplicon studies that provided high taxonomic resolution along with relative sequence abundances. The 16S rRNA gene amplicons from 1552 samples were grouped into eight types of environments (Fig. 5a and Table S5). A total of 811 samples were from inland environments, while others were from marine environments, with each biotope showing a somewhat different microbial community (Fig. 5b). Based on the alpha diversity analysis, marine sediment and soil biotopes harbored more OTUs compared with other biotopes (Fig. S5). Bradymonabacteria was detected in 348 of 741 marine samples (relative abundance $>0.01 \%$ ) but only 20 of 544 soil samples (Fig. 5a). All samples were sorted into an ordination diagram based on the similarity of 
Table 1 The features of 3 different types of bacterial predators

\begin{tabular}{|c|c|c|c|c|c|c|c|}
\hline $\begin{array}{l}\text { Current predator } \\
\text { type }\end{array}$ & $\begin{array}{l}\text { Redefined } \\
\text { predator } \\
\text { type }\end{array}$ & $\begin{array}{l}\text { Prey } \\
\text { dependent/ } \\
\text { independent }\end{array}$ & $\begin{array}{l}\text { Metabolic } \\
\text { pathway } \\
\text { deficiencies }\end{array}$ & $\begin{array}{l}\text { Pure- } \\
\text { culture } \\
\text { cultivable }\end{array}$ & $\begin{array}{l}\text { Storing nutrients as } \\
\text { polymers }\end{array}$ & $\begin{array}{l}\text { Predation } \\
\text { strategy }\end{array}$ & $\begin{array}{l}\text { Predation } \\
\text { specificity }\end{array}$ \\
\hline Obligate & Obligate & $\begin{array}{l}\text { Completely } \\
\text { prey- } \\
\text { dependent }\end{array}$ & High & $\begin{array}{l}\text { Extremely } \\
\text { difficult }\end{array}$ & None & $\begin{array}{l}\text { Contact- } \\
\text { dependent }\end{array}$ & Gram-negative \\
\hline Bradymonabacteria & Facultative & $\begin{array}{l}\text { Facultatively } \\
\text { prey- } \\
\text { dependent }\end{array}$ & High & Difficult & $\begin{array}{l}\text { Polyhydroxyalkanoates, } \\
\text { polyphosphate, and } \\
\text { alkanes }\end{array}$ & $\begin{array}{l}\text { Contact- } \\
\text { dependent }\end{array}$ & $\begin{array}{l}\text { Gram-negative } \\
\text { and Gram- } \\
\text { positive }\end{array}$ \\
\hline Facultative & Opportunistic & $\begin{array}{l}\text { Prey- } \\
\text { independent }\end{array}$ & Low & Normal & Polyphosphate $^{a}$ & $\begin{array}{l}\text { Mostly } \\
\text { contact- } \\
\text { independent }\end{array}$ & $\begin{array}{l}\text { Gram-negative } \\
\text { and Gram- } \\
\text { positive }\end{array}$ \\
\hline
\end{tabular}

${ }^{\mathrm{a}} \mathrm{A}$ polyphosphate accumulation pathway was found in genomes but not determined by experiments

communities (Fig. 5b). Saline biotopes were clearly separated from nonsaline biotopes (Fig. S6), suggesting that salinity was a significant factor in shaping microbial communities. For each biotope, the relative abundance of Bradymonadales in the saline environments (i.e., seawater and saline lake sediment) was significantly higher than that in the nonsaline environments (i.e., nonsaline soil and nonsaline water $)(P \leq 0.0001$, Fig. $5 c)$. The distribution analysis was consistent with the genomic feature analysis (Fig. 2), in which several genes encoding sodium symporters and $\mathrm{Na}^{+} / \mathrm{H}^{+}$antiporters were found in the genomes, suggesting a beneficial effect of salinity on Bradymonabacteria.

In addition, we compared the relative abundance of Bradymonadales with those of two orders of well-known predatory bacteria, Bdellovibrionales and Myxococcales [12, 37, 38]. We found that Myxococcales and Bdellovibrionales were also globally distributed (Fig. S7); however, Myxococcales were more commonly distributed in soil and sediment environments, while Bdellovibrionales were more likely to be found in freshwater and seawater (Fig. S7). The total relative abundances of Bradymonadales, Bdellovibrionales, and Myxococcales ranged from 0.7 to $6.4 \%$ of the total prokaryotic microbes in all 1552 samples (Fig. S8a). The mean relative abundance of Bradymonadales (0.5\%) was similar to that of Bdellovibrionales $(0.6 \%)$ when both were detected in environmental samples (Fig. S8b). In contrast, Bradymonadales was one of the most abundant known predatory bacteria in saline lake sediment and saline lake water (Fig. S8c).

To further determine how salinity affected the relative abundance of Bradymonadales, we used the Gaodao multipond salterns as a model and applied 16S rRNA gene amplicon, fluorescence in situ hybridization (FISH) (Tables S6 and S7), and real-time PCR analyses (Figs. S8d and S9). The results showed that Bradymonadales appeared in all the tested multipond saltern datasets, accounting for an average of $0.74 \%$ of all bacterial sequences and more than $1.0 \%$ relative abundance within the range of 80 and $265 \mathrm{~g} / \mathrm{L}$ salinity (Fig. S8d), significantly higher than those of Bdellovibrionales and Myxococcales. Bradymonadales may exhibit different correlations with prey at different abundances, a possibility that will require further study. In addition, fluorescence in situ hybridization (FISH) (Tables S6 and S7) and real-time PCR experiments were performed, and the results showed a relative cell abundance of Bradymonadales of up to $0.6 \%$ and a gene copy numbers ratio as high as $1.96 \%$ in sediments with salinity $80 \mathrm{~g} / \mathrm{L}$ (Fig. S9). These findings support those of the global analysis (Fig. S8c) and suggest that Bradymonadales may be a dominant bacterial predator in some specific saline environments.

To explore the diversity and distinct evolution of bradymonabacterial subgroups in different biotopes, we performed a phylogenetic analysis of nearly full-length $16 \mathrm{~S}$ rRNA gene sequences of diverse origin by maximum likelihood inference (Table S6). A total of 187 OTUs were detected and found to form six sequence clusters (Fig. 6a). Almost $87.2 \%$ of the representative sequences originated from saline biotopes (such as seawater, marine sediments, salterns, corals, and saline lakes). Since bradymonabacterial subgroups may be selectively distributed in local biotopes, we investigated the relative abundance of each subgroup throughout the 127 representative samples in which the relative abundance of Bradymonadales was above $1 \%$ of total $16 \mathrm{~S}$ rRNA gene reads (Fig. 6b). Five of the 6 bradymonabacterial subgroups showed significantly higher abundance in saline environments. Cluster- 2 and cluster- 6 were mainly observed in seawater biotopes, whereas cluster-3 was mainly observed in marine sediment and saline lake sediment (Fig. 6b), consistent with the environments of the cultured strains. Cluster- 1 and cluster- 4 were both detected in marine sediment and seawater biotopes. Cluster- 5 lineages tended to occur in both freshwater and seawater biotopes (Fig. 6b).

\section{Discussion}

In all ecosystems, predation is an important interaction among living organisms. Bacterial predators are 


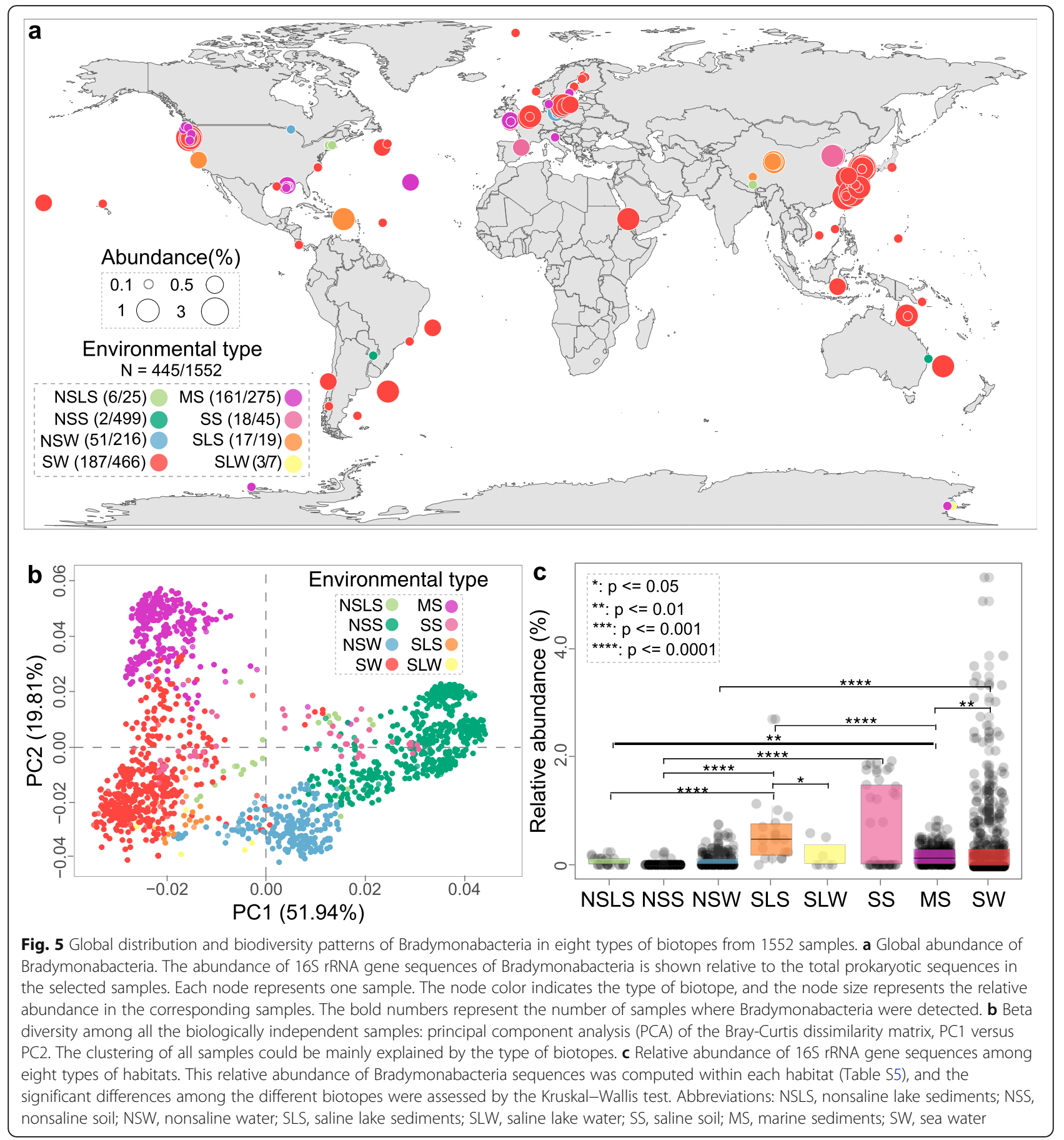

proposed to play an important role in controlling and shaping bacterial populations in diverse environments $[3,39]$. However, despite their ecological importance, only a few examples of predatory bacteria have been studied in depth. Recently, many predatory bacteria from various phyla have been isolated from different environments; however, most of their predatory lifestyle strategies and adaptations remain unclear. This study systematically analyzed the predatory lifestyle adaptations, global distribution, and diversity of
Bradymonadales; highlighted the ecological role of Bradymonadales; and provided a framework for the categorization of the known predatory bacteria.

In our study, based on comparative genomic and physiological analyses, Bradymonabacteria were identified as a novel group of bacterial predators with versatile survival strategies that are transitional types between "obligate" predators and the so-called facultative predators (Table 1). Similar to the obligate predators, 


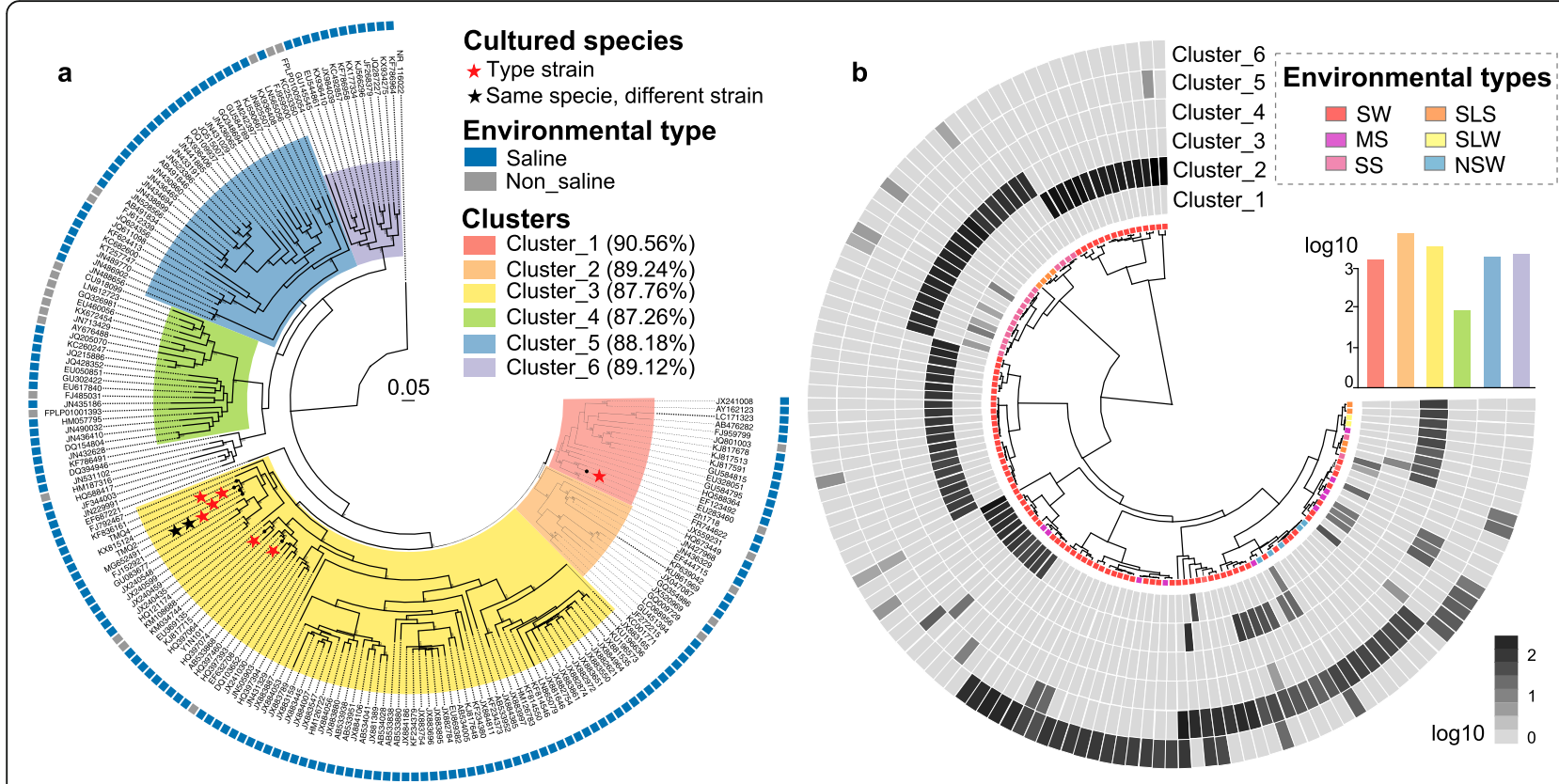

Fig. 6 Phylogeny of 6 proposed subgroups of Bradymonabacteria. a Maximum likelihood phylogenetic tree of Bradymonabacteria based on 187 representative 16S rRNA gene sequences (> 1200 bp) dereplicated at a 98.5\% cutoff. The subgroups from Cluster_1 to Cluster_6 were colored in the corresponding leaves of the tree and are shown with the similarity of each subgroup. The outer colored square indicates the sequence of the original biotope: nonsaline (gray) and saline (blue). Pentagram represents cultured Bradymonabacteria in our laboratory. All 165 rRNA gene sequences of Bradymonabacteria and the RAxML phylogenetic tree are available in Table S6. b The coverage of each subgroup of Bradymonabacteria for 127 samples. The abundance of Bradymonabacteria is expressed relative to the total number of prokaryotic sequences in the corresponding samples. The biotope types are shown by the colored nodes located under each leaf of the cluster. The bar graph indicates the read number of each cluster in the 127 samples

Bradymonabacteria have multiple metabolic deficiencies. Their incomplete pathways might be important for preydependent growth, as the precursor compounds could be acquired from predation. In addition, the loss of genes in the fatty acid biosynthetic pathway was notable, because fatty acids are integral components of the cellular membrane, and their synthesis is considered to be a housekeeping function of cells [40]. Thus, these organisms may incorporate exogenous fatty acids from prey bacteria into their membrane phospholipids using their high copy number of long-chain fatty acid transport proteins [41] (Fig. 3). Unlike the currently called "facultative" predators, the multiple gene loss observed in Bradymonabacteria may render them more dependent on prey for their lost metabolic functions and could also provide a selective advantage by conserving predators' limited resources [42]. However, the sequenced genomes of Bradymonabacteria were surprisingly large $(5.0$ to $8.0 \mathrm{Mb}$, Fig. S1a), suggesting that Bradymonabacteria are far from obligate parasites, with seemingly none of the reductive evolution that results from a parasitic lifestyle in bacteria such as Mycobacterium leprae [43]. The large size of their genomes may be indicative of the vast range of genes required for Bradymonabacteria to both effectively tolerate the absence of prey and carry out predation.
In contrast to most predators, Bradymonabacteria can synthesize many nutrient polymers, such as polyphosphate, PHA, and alkane molecules. Exopolyphosphatase catalyzes the hydrolysis of terminal phosphate residues from polyphosphate chains, accompanying the production of ATP and thus playing a role in the production of energy [44]. Bradymonadales cells may accumulate polyphosphate in the phosphate-rich zone, using it as an energy source [45]. Meanwhile, PHA granules are synthesized as sinks of excess carbon and are used as carbon and energy reserves in starvation conditions [46]. Under nutrient starvation, maintenance energy and free amino acids can be provided by endogenous substrates such as PHAs and polyphosphate [47, 48]; this ability may be an important feature for the survival of Bradymonabacteria during intervals without predation. This feature is interesting among bacterial predators, as it is commonly found in animal predation. For example, the bear can store fat in its body to ensure that it will survive the long winter. In addition, Bradymonabacteria may also synthesize alkanes to maintain cell membrane integrity [36] and complement its poor fatty acid synthesis ability. Thus, these multiple auxotrophies and ability to synthesize nutrient polymers confer on Bradymonabacteria a versatile survival strategy for natural 
environments, which contrasts with that of the currently known "obligate" or "facultative" predators.

As bacterial predators, Bradymonabacteria have developed a wide range of mechanisms to attack their prey. Although genes involved in OMV-like biosynthesis were detected in most genomes, the fermentation supernatant of Bradymonabacteria showed no antibacterial activity, suggesting that bradymonabacterial predation depends on the cell contact, which is different from that of the currently known facultative predators. Contact-dependent predation mechanisms allow predators to attach to the prey and then carry out predation. This prey-dependent process has a relatively low energy cost and could prevent secretory virulence factors from being diluted by the surrounding environment [49]. Bradymonabacteria also has T4P, which could pull adherent bacteria into close association with other bacteria [50]. T4P could also transport bound substrates such as DNA [51] into the periplasm and export exoproteins across the outer membrane [52]. Contact-dependent type III secretion systems have also been found in Bradymonabacteria and are reported to be capable of moving virulence factors across bacterial outer membranes and directly across the host cell membrane into the cytoplasm of a host cell [53]. However, no reports have indicated that the type III secretion system is involved in direct combat between bacteria. Whether type III secretory complexes could penetrate the bacterial cell wall is unknown. Further gene knockout experiments and systematic TEM analysis should be performed to identify whether and how the type III secretion system works during predation.

Our biogeographic analysis suggested that Bradymonabacteria are mainly distributed in saline environments, and some other studies have also detected Bradymonadales in hypersaline soda lake sediments [25], suggesting that saline environments could be enriched in these bacteria. Our genome analysis also showed that Bradymonadales had many genes encoding sodium symporters and $\mathrm{Na}^{+} / \mathrm{H}^{+}$antiporters to maintain osmotic pressure in saline environments. These findings supported the global analysis (Figs. 5 and S8c), suggesting that Bradymonadales might be a dominant bacterial predator in some specific saline environments compared with Bdellovibrionales and Myxococcales. The analysis of the complex intragroup phylogeny of the 6 subgroups of Bradymonabacteria revealed that distinct evolutionary bradymonabacterial subgroups had arisen in different biotopes, suggesting the occurrence of adaptive evolution specific to each habitat. Patterns related to salinity status also suggest that most Bradymonadales are halophiles [17].

Bradymonabacteria had a very high predation efficiency on bacteria within the phylum Bacteroidetes. Members of the phylum Bacteroidetes are one the most abundant groups of bacteria in the ocean [54]. Thus, a high predation efficiency on Bacteroidetes may indicate that Bradymonabacteria has important roles in regulating Bacteroidetes communities in oceans. Furthermore, Bradymonabacteria had a high predation efficiency on Flavobacteria and Proteobacteria, some of which are commensal bacteria in fish [55], suggesting that Bradymonabacteria may be involved in fish microbiome dysbiosis. In addition, Bradymonadales were detected in coral samples, as Bradymonabacteria have a wide range of prey, including the coral pathogen Vibrio harveyi, suggesting that Bradymonabacteria may protect coral hosts by consuming potential pathogens [39]. The exact ecological roles of this group in different environments should be determined in further studies.

\section{Conclusion}

The unique metabolic pathways of Bradymonabacteria, which include conspicuous metabolic deficiencies similar to those of obligate predators but with a more effective starvation stress response mechanism, provide these bacteria with transitional survival models between "obligate" and so-called facultative predators. We suggest that Bradymonabacteria, as facultative prey-dependent predators, can be renamed as facultative predators. In addition, the currently used "facultative" predators term can be replaced by opportunistic predators, which are prey-independent predators. Thus, we propose a framework to categorize the current bacterial predators into 3 groups: (i) obligate predators (completely prey-dependent), such as most of the BALOs; (ii) facultative predators (facultatively prey-dependent), such as the Bradymonabacteria cultured in the present study; and (iii) opportunistic predators (prey-independent), such as Myxobacteria and Lysobacter sp. (Table 1). This categorization replaces the currently known "facultative" predators with opportunistic predators and will be helpful for further study of the different ecological importance of each type of bacterial predator. The evolution of bacterial predation in these three groups of predators should also be studied in the future to better understand the significance of predation to biological evolution.

Our study highlights the ecological role of Bradymonadales in saline environments. Given their substantial sequence and cell frequencies in the saline environment and their storage of nutrients as polymers in cells during predation, Bradymonadales may have an alternative way of regulating global nutrient cycling. To better understand the impact of bradymonabacterial predation on regulating biogeochemical cycling, predation mutants and microcosms need to be developed in further studies.

\section{Methods}

Predation experiments

To explore the predation of Bradymonabacteria, we used Bradymonas sediminis $\mathrm{FA} 350^{\mathrm{T}}$ and Lujinxingia litoralis $\mathrm{B} 210^{\mathrm{T}}$ as representative strains. All candidate prey strains 
were obtained from our laboratory. Cells were centrifuged, washed, and concentrated in seawater to a final $\mathrm{OD}_{600}$ of 3.0 for predator strains and 6.0 for candidate prey strains. Drops of $5.0 \mu \mathrm{l}$ of the predator strain suspensions were deposited on the surfaces of agar plates and allowed to dry. Next, $20.0 \mu \mathrm{l}$ drops of each different candidate prey strain suspension were placed near the predator spot. The plates were incubated at $33^{\circ} \mathrm{C}$, and images were taken after $48 \mathrm{~h}$ with a digital camera. To detect PHA accumulation, the granules were stained with the Nile red component of Nile blue A.

\section{Genome sequencing and comparative genome analyses}

To explore the potential metabolic capacity of bacterial predators, we sequenced 3 complete genomes and 6 draft genomes of all currently known Bradymonabacteria isolate strains. The genomic DNA of all strains was extracted with a DNA extraction kit (TaKaRa Bio) according to the manufacturer's instructions. For strains $\mathrm{FA350}{ }^{\mathrm{T}}, \mathrm{V} 1718$, and $\mathrm{YN} 101$, complete genome sequencing was performed by Nanjing CocoBio Co., China, using the Illumina HiSeq platform accompanied with the SMRT platform to build Illumina PE and Pacbio libraries. The single-molecule sequencing data assembly was accomplished using SOAPdenovo v2.04 and Celera Assembler v8.0, and the results were rectified through BLAST searches in the BlastR database. The de novo assembly of the scaffolds was performed using Celera Assembler 8.0, which were then overlapped and trimmed using GapCloser v1.12 (SOAPdenovo-related software) [18]. Draft genome sequencing of the other 6 strains was performed by Shanghai Personal Biotechnology Co., Ltd. (Shanghai, China) using Solexa paired-end sequencing technology [2]. A library with an average fragment length of $400 \mathrm{bp}$ was constructed, and the final genomes were assembled using SOAPdenovo version 2.04 [56]. We also retrieved 37 predator genomes from NCBI (including 4 metagenome-assembled genomes). tRNA and gene prediction were performed using tRNAscan and prodigal, respectively. The genome-based metabolic potential of the bacterial predators was predicted by BlastKOALA (https://www.kegg.jp/blastkoala/). The average nucleic acid identities among the 9 cultured Bradymonabacteria strains were calculated using pyani (https:// github.com/widdowquinn/pyani), and the percentage of conserved proteins (POCP) in each strain was calculated as described previously by Qin et al. [57].

\section{Electron microscopy analyses}

We selected Algoriphagus marinus am2, which is smaller than the predator Bradymonas sediminis $\mathrm{FA} 350^{\mathrm{T}}$, as prey. Bradymonas sediminis $\mathrm{FA}_{350^{\mathrm{T}}}$ and Algoriphagus marinus am2 were cultured separately to the exponential growth phase, adjusted to the same OD value, mixed together, and cocultured on marine agar medium at $33^{\circ} \mathrm{C}$ for $68 \mathrm{~h}$.

For TEM analysis, mixed culture samples were supported on carbon/formvar-coated copper grids. The grids were inverted over a drop of $1 \%$ uranyl acetate. Thin sections were prepared with the predator-prey cocultures at $68 \mathrm{~h}$ incubation. The samples were mixed with $0.5 \mathrm{ml}$ of $2 \%$ glutaraldehyde in $0.1 \mathrm{M}$ sodium cacodylate buffer, centrifuged and resuspended in $1 \mathrm{ml}$ of the same solution for $3 \mathrm{~h}$. The cells were washed in cacodylate buffer, fixed with $1 \%$ osmium tetroxide, and encased in agar. The agar-encased cells were then fixed in $2 \%$ uranyl acetate, dehydrated through an ethanol series, and embedded in Epon resin. Thin sections were cut and stained with uranyl acetate and lead citrate. Specimens were examined with a JEM-1200EX electron microscope operated at $80 \mathrm{kV}$.

For SEM analysis, mixed culture samples were washed 3 times with PBS and fixed for $1 \mathrm{~h}$ in $2.5 \%$ glutaraldehyde in sodium cacodylate buffer $(0.1 \mathrm{M}, \mathrm{pH} 7.2)$. To dehydrate the bacteria, the EM grids underwent a series of washes in increasing concentrations of ethanol (25, 50,75 , and 96\%) and placed in a vacuum overnight. The samples were coated with gold and observed using a Nova NanoSEM 450.

\section{Dual transcriptomic analyses}

To determine the gene expression profiles of the type strain $\mathrm{FA} 350^{\mathrm{T}}$, Algoriphagus marius $\mathrm{am} 2^{\mathrm{T}}$ was used as prey due to its cell morphology being different from $B$. sediminis $\mathrm{FA} 350^{\mathrm{T}}$. Moreover, B. sediminis $\mathrm{FA} 350^{\mathrm{T}}$ predated A. marius am $2^{\mathrm{T}}$ well, and the two species have a distant evolutionary relationship that was helpful for further gene mapping analysis. A pure culture of $\mathrm{FA} 350^{\mathrm{T}}$ and a coculture of $\mathrm{FA} 350^{\mathrm{T}}$ with the prey $A$. marinus am2 were cultured on marine agar medium at $33^{\circ} \mathrm{C}$ for $0 \mathrm{~h}, 68 \mathrm{~h}$, and $120 \mathrm{~h}$, respectively. Mixed-culture cells sedimented by centrifugation and washed, and the resulting pellets stored at $-80^{\circ} \mathrm{C}$ prior to RNA extraction. Each time point was collected in triplicate $(n=3)$ for further transcriptomic analysis. RNA was extracted using an miRNEasy mini kit (Qiagen 217004), rRNA was removed using a Ribo-Zero Magnetic kit (Bacteria) from Epicentre (MRZB12424), and cDNA library construction was performed with a TruSeq Stranded mRNA library preparation kit from Illumina (RS-122-2101) [58]. Sequencing was carried out on a HiSeq sequencer at Novogene Co., Ltd. (Beijing, China).

\section{Transcriptome mapping and differential expression analysis}

For transcriptomic analysis of mixed culture samples (dual transcriptomic analysis), total RNA sequences were mapped to the complete genome of $\mathrm{FA} 350^{\mathrm{T}}$ using the method 
reported by Westermann et al. [59]. Before downstream processing, trimmomatic was used to clean the reads to remove adaptor sequences and leading and trailing bases with quality thresholds below 20, perform sliding window trimming (with parameters 4:15), and remove reads less than $36 \mathrm{bp}$ in length. After cleaning, the remaining paired reads were mapped to the respective genomes to calculate expression values. The reference genomes used were $B$. sediminis FA350 ${ }^{\mathrm{T}}$ (accession: CP030032.1) and A. marinus am 2 (accession: MSPQ00000000.1). The output fragments per kilobase of transcript per million mapped reads (FPKM) were calculated for further analysis. Significantly upregulated and downregulated genes were defined using a false discovery rate of less than 0.001 , a $P$ value of $<0.05$, and a minimum 1 $\log 2$ (fold)-change of gene expression.

\section{Phylogenetic analysis of bradymonabacterial type IV pili} An unrooted, maximum likelihood phylogeny shows relationships between the type IVa, type IVb, and type IVc pili and the archaellum (archaeal flagellum) and the T2SS and T4SS extension ATPases. The protein aminoacid sequences were aligned with mafft and used to estimate a maximum likelihood phylogeny with RAxML under the JTT substitution model with gammadistributed rate variation. The protein amino-acid sequences of Bradymonas were annotated by RAST (Rapid Annotation using Subsystem Technology) [60]. The other protein amino acid sequences were obtained from other research supplementary materials [61].

\section{Biogeographic distribution database construction}

All the 16S rRNA gene sequences analyzed in this paper were downloaded from the European Nucleotide Archive (https://www.ebi.ac.uk/ena, ENA) during or before December 2018. As a result, we collected 1552 samples from 102 projects or studies: 25 from nonsaline lake sediments (NSLS), 275 from marine sediments (MS), 499 from nonsaline soil (NSS), 45 from saline soil (SS), 216 from nonsaline water (NSW), 19 from saline lake sediments (SLS), 466 from seawater (SW), and 7 from saline lake water (SLW) (Table S5).

\section{Microbial community composition}

The raw 16S rRNA gene reads were filtered with UCHIME. Quality filtering, chimera detection, dereplication, clustering into OTUs, and assigning taxonomic information were performed using VSEARCH [62]. The SILVA database Ref_SSU release 132 was used as a reference taxonomic database (https://www.arb-silva.de/). Alpha diversity indices (Shannon, Simpson, Good's coverage and Ace) detailing the microbial community composition within each sample were calculated using scikit-bio (http://scikit-bio.org/) in Python, and alpha diversity indices (Chao1) were calculated using the package fossil (https://www.rdocumentation.org/packages/fossil) in R. For estimating community dissimilarities, the Bray-Curtis dissimilarity was calculated between 1551 samples (total samples: 1552) by vegan in $\mathrm{R}$ based on the relative abundance of order taxonomy level.

\section{Phylogenetic analyses}

Both RAxML [63] and FastTree [64] were employed to construct the Bradymonabacteria phylogenetic tree. Given both the topology of the phylogenetic tree and its good coverage of all Bradymonabacteria lineages, we established the phylogenetic tree using 187 representative Bradymonabacteria $16 \mathrm{~S}$ rRNA gene sequences, which were all longer than 1200 bp (at $98.5 \%$ cutoff). These sequences were aligned using mafft. The Bradymonabacteria subgroup designations were confirmed when one subgroup with $>10$ representative sequences was monophyletic by two phylogenetic trees constructed by different programs using the maximum likelihood approach [65]. The environmental type (i.e., saline and nonsaline) of each Bradymonabacteria sequence in the tree was collected from GenBank. A genome-based phylogeny of bacterial predators and 9 cultured Bradymonabacteria strains was constructed using core genes [66], and trees were constructed using RAxML [63]. All phylogenetic trees were drawn using ggtree [67] in R.

\section{Quantitative real-time PCR}

The environmental DNA samples extracted in the previous step were used for qPCR experiments in order to detect the abundance of bacteria and Bradymonadales in each sample. The primer pair composed of $341 \mathrm{~F}\left(5^{\prime}-\right.$ CCTACGGGAGGCAGCAG-3') and 534R (5'-ATTA CCGCGGCTGCTGGCA-3') was used for quantification of bacteria [22]. A Bradymonadales-specific primer set composed of qBRA1295F (5'-CTCAGTWCGGATYGYAGTCTG-3') and qBRA1420R (5'-GTCACYGACT TCTGGAGCAARYG-3'), which was designed in the present study and generated an amplicon of 148 bases, was used for quantification of Bradymonadales. The specificity and coverage test of the primers were described in the Supplementary Materials (Supplementary Methods and Results, Fig. S10 and S11, Tables S8 and S9). Reactions for each sample were carried out in an ABI StepOnePlus thermal cycler under the following conditions: an initial denaturation step at $95^{\circ} \mathrm{C}$ for 10 min and then 40 cycles of $15 \mathrm{~s}$ at $95^{\circ} \mathrm{C}$ and $30 \mathrm{~s}$ at $60^{\circ} \mathrm{C}$. The reaction was performed in a total volume of $20 \mu \mathrm{l}$, composed of $10 \mu \mathrm{l} 2 \mathrm{X}$ Universal SYBR Green Fast qPCR Mix (ABclonal), $0.4 \mu \mathrm{l}$ of each primer $(10 \mu \mathrm{M}), 1 \mu \mathrm{l}$ of sample, and $8.2 \mu \mathrm{l}$ of MiliQ water. The Plasmid DNA Standard was constructed by introducing the $16 \mathrm{~S}$ rDNA gene amplified from Bradymonas sediminis $\mathrm{FA} 350^{\mathrm{T}}$ into 
the pMD18-T Vector (TaKaRa) following the manufacturer's instructions. The plasmid was isolated and purified using a MiniBEST Plasmid Purification Kit (TaKaRa). DNA copy number was determined by the concentration and relative molecular weight of the Plasmid DNA. For each QPCR assay, the plasmid aliquot was serially diluted to produce concentrations ranging from $10^{9}$ to $10^{3}$ DNA copies/ $\mu$ l to generate calibration curves. Each sample was measured in triplicate, and negative controls (no template NTC) were included.

\section{Supplementary information}

Supplementary information accompanies this paper at https://doi.org/10 1186/s40168-020-00902-0.

\section{Additional file 1: Figure S1. The General features of bacterial} predators. Figure S2. General gene expression profiles of Bradymonas sediminis FA350 during mix-culturing with prey Algoriphagus marines am2. Figure S3. Gene expression profiles of Bradymonas sediminis FA350 during mix-culturing with prey Algoriphagus marines am2. Figure S4. Phylogenetic analysis of secretion system machinery reveals a distinct tad type IVb subtype of type IV pili. Figure S5. The alpha diversity in 1,552 samples. Figure S6. Principal component analysis of different samples associated with saline status. Figure S7. Global distribution of Myxococcales and Bdellovibrionales in eight different biotopes from 1,552 samples. Figure S8. The relative abundance of Bradymonadales, Myxococcales, and Bdellovibrionale. Figure S9. Cell abundance and relative abundance of gene copy number of Bradymonadales from solar saltern sediments. Figure S10. Specificity test of the Quantitative real-time PCR primers. Figure S11. Quantitative real-time PCR amplification detection and the standard curve.

Additional file 2: Table S1. Detailed information of organisms on the phylogenetic tree

Additional file 3: Table S2. Detailed genes information for figure 3. Additional file 4: Table S3. Detailed genes information for figure 4. Additional file 5: Table S4. Detailed key genes expression changed during predation.

Additional file 6: Table S5. Detailed information of 16S rRNA genes amplicon samples used in this study.

Additional file 7: Table S6. Detailed information of the representative 165 rRNA gene sequences.

Additional file 8: Table S7. Probes designed and optimized in this study.

Additional file 9: Table S8. Specificity and coverage of primers qBRA1295F and qBRA1420R using the SILVA database SSU r138 Ref NR.

\section{Acknowledgements}

This work was supported by the National Natural Science Foundation of China (31770002 and 41876166), National Science and Technology Fundamental Resources Investigation Program of China (2019FY100700)

\section{Consent for publications}

Not applicable

\section{Authors' contributions}

DSM, GJC, JZ, and ZJD designed the study. SW carried out TEM, SEM, and transcriptome analyses. ZZD carried out FISH and real-time PCR analysis. DSM, QYL, SW, XPW, and RT performed bioinformatic analyses. DSM and ZJD analyzed data and wrote the paper. JYN, AZ, and YY improved the paper writing. All authors read and approved the manuscript

\section{Availability of data and materials}

The genomes of cultured bradymonabacteral isolates have been deposited in the NCBI database under GenBank accession numbers CP042467.1
(Bradymonadales strain V1718), CP042468.1 (Bradymonadales strain YN101), VOPX00000000.1 (Bradymonadales strain TMQ1), VOSL00000000.1

(Bradymonadales strain TMQ2), QRGZ00000000.1 (Bradymonadales strain TMQ3), VOSM00000000.1 (Bradymonadales strain TMQ4), CP030032.1 (Bradymonas sediminis FA350 ${ }^{\top}$ ), QHKO00000000.1 (Lujinxingia litorali B210 ${ }^{\top}$ ), and SADD00000000.1 (Lujinxingia sediminis SEH01 ${ }^{\top}$ ). The genomes of uncultured Bradymonabacteria have been deposited in the NCBI database under GenBank accession numbers PWKZ00000000.1 (Bradymonadales bin CSSed10 215), PWTN00000000.1 (Bradymonadales bin CSSed11_191), PXAJ00000000.1 (Bradymonadales bin T3Sed10_204), and PWZZO00000000.1 (Bradymonadales bin T3Sed10_190). The 16S rRNA gene data sets of Gaodao salterns have been deposited in the Sequence Read Archive under accession number SRP217756 for all the samples. The transcriptome sequences for predation of $F A 350^{\top}$ have been deposited in the NCBI database under accession numbers PRJNA559243 and PRJNA559253. All Bradymonabacteral isolates have been deposited at the Shandong Infrastructure of Marine Microbial Resources hosted by the Laboratory of Marine Microbiology at Shandong University (http://www.sdum.wh.sdu.edu.cn/search.html?itemld= 14). All Bradymonabacteral isolates are available upon request. The bash, $R$, and python scripts for this study are available on the GitHub: https://github. com/2015qyliang/BradymonabacteriaAnalysis.

Ethics approval and consent to participate Not applicable

\section{Competing interests}

No conflict of interest exists in the submission of this manuscript, and the manuscript has been approved by all authors for publication. The authors declare that they have no competing interests.

\section{Author details}

${ }^{1}$ State Key Laboratory of Microbial Technology, Institute of Microbial Technology, Shandong University, No. 72, Jimo Binhai Road, Jimo, Qingdao 266237, China. ${ }^{2}$ Marine College, Shandong University, Weihai 264209, China. ${ }^{3}$ Institute for Environmental Genomics, University of Oklahoma, Norman, Oklahoma 73019, USA. ${ }^{4}$ State Key Joint Laboratory of Environment Simulation and Pollution Control, School of Environment, Tsinghua University, Beijing 100084, China.

Received: 6 January 2020 Accepted: 27 July 2020

Published online: 31 August 2020

\section{References}

1. Young KD. The selective value of bacterial shape. Microbiol Mol Biol R. 2006; 70(3):660-703.

2. Chauhan A, Cherrier J, Williams HN. Impact of sideways and bottom-up control factors on bacterial community succession over a tidal cycle. P Natl Acad Sci USA. 2009;106(11):4301-6.

3. Johnke J, Cohen Y, de Leeuw M, Kushmaro A, Jurkevitch E, Chatzinotas A Multiple micro-predators controlling bacterial communities in the environment. Curr Opin Biotech. 2014;27:185-90.

4. Li HH, Chen C, Sun QP, Liu RL, Cai JP. Bdellovibrio and like organisms enhanced growth and survival of Penaeus monodon and altered bacterial community structures in its rearing water. Appl Environ Microb. 2014;80(20): 6346-54.

5. Martinez V, Jurkevitch E, Garcia JL, Prieto MA. Reward for Bdellovibrio bacteriovorus for preying on a polyhydroxyalkanoate producer. Environ Microbiol. 2013;15(4):1204-15.

6. Richards GP, Fay JP, Dickens KA, Parent MA, Soroka DS, Boyd EF. Predatory bacteria as natural modulators of Vibrio parahaemolyticus and Vibrio vulnificus in seawater and oysters. Appl Environ Microb. 2012;78(20):7455-66.

7. Williams HN, Lymperopoulou DS, Athar R, Chauhan A, Dickerson TL, Chen $\mathrm{H}$, et al. Halobacteriovorax, an underestimated predator on bacteria: potential impact relative to viruses on bacterial mortality. ISME J. 2016;10(2):491-9.

8. Chen H, Laws EA, Martin JL, Berhane TK, Gulig PA, Williams HN. Relative contributions of Halobacteriovorax and bacteriophage to bacterial cell death under various environmental conditions. Mbio. 2018;9(4):e01202-18.

9. Perez J, Moraleda-Munoz A, Marcos-Torres FJ, Munoz-Dorado J. Bacterial predation: 75 years and counting! Environ Microbiol. 2016;18(3):766-79. 
10. Cabrera G, Perez R, Gomez JM, Abalos A, Cantero D. Toxic effects of dissolved heavy metals on Desulfovibrio vulgaris and Desulfovibrio sp. strains. J Hazard Mater. 2006;135(1-3):40-6.

11. Im H, Dwidar M, Mitchell RJ. Bdellovibrio bacteriovorus HD100, a predator of gram-negative bacteria, benefits energetically from Staphylococcus aureus biofilms without predation. Isme J. 2018;12(8):2090-5.

12. Sockett RE. Predatory lifestyle of Bdellovibrio bacteriovorus. Annu Rev Microbiol. 2009;63:523-39.

13. Hespell RB, Thomashow MF, Rittenberg SC. Changes in cell composition and viability of Bdellovibrio bacteriovorus during starvation. Arch Microbiol. 1974;97(4):313-27.

14. Hobley L, Lerner TR, Williams LE, Lambert C, Till R, Milner DS, et al. Genome analysis of a simultaneously predatory and prey-independent, novel Bdellovibrio bacteriovorus from the river Tiber, supports in silico predictions of both ancient and recent lateral gene transfer from diverse bacteria. BMC Genomics. 2012;13:670.

15. Pasternak Z, Pietrokovski S, Rotem O, Gophna U, Lurie-Weinberger MN, Jurkevitch E. By their genes ye shall know them: genomic signatures of predatory bacteria. Isme J. 2013;7(4):756-69.

16. Tang BL, Yang J, Chen XL, Wang P, Zhao HL, Su HN, et al. A predator-prey interaction between a marine Pseudoalteromonas sp and Gram-positive bacteria. Nat Commun. 2020;11:285.

17. Wang ZJ, Liu QQ, Zhao LH, Du ZJ, Chen GJ. Bradymonas sediminis gen. Nov , sp. nov., isolated from coastal sediment, and description of Bradymonadaceae fam. Nov. and Bradymonadales Ord. Nov. Int J Syst Evol Microbiol. 2015;65(5):1542-9.

18. Wang S, Mu DS, Zheng WS, Du ZJ. Complete genome sequence of Bradymonas sediminis $F A 350^{\top}$, the first representative of the order Bradymonadales. Mar Genomics. 2019;46(4):62-5.

19. Hahn MW, Schmidt J, Koll U, Rohde M, Verbarg S, Pitt A, et al. Silvanigrella aquatica gen. Nov., sp. nov., isolated from a freshwater lake, description of Silvanigrellaceae fam. Nov. and Silvanigrellales Ord. Nov., reclassification of the order Bdellovibrionales in the class Oligoflexia, reclassification of the families Bacteriovoracaceae and Halobacteriovoraceae in the new order Bacteriovoracales Ord. Nov., and reclassification of the family Pseudobacteriovoracaceae in the order Oligoflexales. Int J Syst Evol Microbiol. 2017;67(8):2555-68.

20. Zhou XW, Li SG, Li W, Jiang DM, Han K, Wu ZH, et al. Myxobacterial community is a predominant and highly diverse bacterial group in soil niches. Env Microbiol Rep. 2014;6(1):45-56.

21. Jiang DM, Kato C, Zhou XW, Wu ZH, Sato T, Li YZ. Phylogeographic separation of marine and soil myxobacteria at high levels of classification. ISME J. 2010;4(12):1520-30.

22. Mu DS, Liang QY, Wang XM, Lu DC, Shi MJ, Chen GJ, et al. Metatranscriptomic and comparative genomic insights into resuscitation mechanisms during enrichment culturing. Microbiome. 2018;6(1):230.

23. Guo LY, Li CM, Wang S, Mu DS, Du ZJ. Lujinxingia litoralis gen. Nov., sp. nov. and Lujinxingia sediminis sp. nov., two new representatives in the order Bradymonadales. Int J Syst Evol Microbiol. 2019. https://doi.org/10.1099/ ijsem.0.003556.

24. Kim M, Kang O, Zhang Y, Ren L, Chang X, Jiang F, et al. Sphingoaurantiacus polygranulatus gen. Nov., sp. nov., isolated from high-Arctic tundra soil, and emended descriptions of the genera Sandarakinorhabdus, Polymorphobacter and Rhizorhabdus and the species Sandarakinorhabdus limnophila, Rhizorhabdus argentea and Sphingomonas wittichii. Int J Syst Evol Microbiol. 2016;66(1):91-100

25. Vavourakis CD, Andrei AS, Mehrshad M, Ghai R, Sorokin DY, Muyzer G. A metagenomics roadmap to the uncultured genome diversity in hypersaline soda lake sediments. Microbiome. 2018;6(1):168.

26. Jain C, Rodriguez RL, Phillippy AM, Konstantinidis KT, Aluru S. High throughput ANI analysis of $90 \mathrm{~K}$ prokaryotic genomes reveals clear species boundaries. Nat Commun. 2018:9(1):5114.

27. Gil R, Silva FJ, Pereto J, Moya A. Determination of the core of a minimal bacterial gene set. Microbiol Mol Biol Rev. 2004;68(3):518-37.

28. Avidan O, Petrenko M, Becker R, Beck S, Linscheid M, Pietrokovski S, et al. Identification and characterization of differentially-regulated type IVb pilin genes necessary for predation in obligate bacterial predators. Sci Rep. 2017; 7(1):1013.

29. Duncan MC, Gillette RK, Maglasang MA, Corn EA, Tai AK, Lazinski DW, et al. High-throughput analysis of gene function in the bacterial predator Bdellovibrio bacteriovorus. MBio. 2019;10(3):e01040-19.
30. Dietsche T, Tesfazgi Mebrhatu M, Brunner MJ, Abrusci P, Yan J, FranzWachtel $M$, et al. Structural and functional characterization of the bacteria type III secretion export apparatus. PLoS Pathog. 2016;12(12):e1006071.

31. Li J, Chen G, Wu H, Webster JM. Identification of two pigments and a hydroxystilbene antibiotic from Photorhabdus luminescens. Appl Environ Microbiol. 1995;61(12):4329-33.

32. Nevermann J, Silva A, Otero C, Oyarzun DP, Barrera B, Gil F, et al. Identification of genes involved in biogenesis of outer membrane vesicles (OMVs) in Salmonella enterica Serovar Typhi. Front Microbiol. 2019;10:104.

33. Liu C, Liu Y, Xu XX, Wu H, Xie HG, Chen L, et al. Potential effect of matrix stiffness on the enrichment of tumor initiating cells under threedimensional culture conditions. Exp Cell Res. 2015;330(1):123-34.

34. Grote J, Schott T, Bruckner CG, Glockner FO, Jost G, Teeling H, et al. Genome and physiology of a model Epsilonproteobacterium responsible for sulfide detoxification in marine oxygen depletion zones. Proc Natl Acad Sci U S A. 2012;109(2):506-10.

35. Fukui T, Shiomi N, Doi Y. Expression and characterization of (R)-specific enoyl coenzyme a hydratase involved in polyhydroxyalkanoate biosynthesis by Aeromonas caviae. J Bacteriol. 1998;180(3):667-73.

36. Sukovich DJ, Seffernick JL, Richman JE, Hunt KA, Gralnick JA, Wackett LP. Structure, function, and insights into the biosynthesis of a head-to-head hydrocarbon in Shewanella oneidensis strain MR-1. Appl Environ Microbiol. 2010;76(12):3842-9.

37. Rendulic S, Jagtap P, Rosinus A, Eppinger M, Baar C, Lanz C, et al. A predator unmasked: life cycle of Bdellovibrio bacteriovorus from a genomic perspective. Science. 2004;303(5658):689-92.

38. Munoz-Dorado J, Marcos-Torres FJ, Garcia-Bravo E, Moraleda-Munoz A, Perez J. Myxobacteria: moving, killing, feeding, and surviving together. Front Microbiol. 2016;7:781.

39. Welsh RM, Zaneveld JR, Rosales SM, Payet JP, Burkepile DE, Thurber RV Bacterial predation in a marine host-associated microbiome. Isme J. 2016; 10(6):1540-4.

40. Nayfach S, Shi ZJ, Seshadri R, Pollard KS, Kyrpides NC. New insights from uncultivated genomes of the global human gut microbiome. Nature. 2019; 568(7753):505-10

41. Black PN, DiRusso CC. Transmembrane movement of exogenous long-chain fatty acids: proteins, enzymes, and vectorial esterification. Microbiol Mol Biol Rev. 2003:67(3):454-72.

42. Morris JJ, Lenski RE, Zinser ER. The Black queen hypothesis: evolution of dependencies through adaptive gene loss. Mbio. 2012;3(2):00036-12.

43. Cole ST, Eiglmeier K, Parkhill J, James KD, Thomson NR, Wheeler PR, et al. Massive gene decay in the leprosy bacillus. Nature. 2001;409(6823):1007-11.

44. Saunders AM, Mabbett AN, McEwan AG, Blackall LL. Proton motive force generation from stored polymers for the uptake of acetate under anaerobic conditions. FEMS Microbiol Lett. 2007:274(2):245-51.

45. Kim KS, Rao NN, Fraley CD, Kornberg A. Inorganic polyphosphate is essential for long-term survival and virulence factors in Shigella and Salmonella spp. P Natl Acad Sci USA. 2002;99(11):7675-80

46. Ratcliff WC, Kadam SV, Denison RF. Poly-3-hydroxybutyrate (PHB) supports survival and reproduction in starving rhizobia. FEMS Microbiol Ecol. 2008; 65(3):391-9.

47. Moller L, Laas P, Rogge A, Goetz F, Bahlo R, Leipe T, et al. Sulfurimona subgroup GD17 cells accumulate polyphosphate under fluctuating redox conditions in the Baltic Sea: possible implications for their ecology. Isme J. 2019;13(2):482-93x

48. Kuroda A, Nomura K, Ohtomo R, Kato J, Ikeda T, Takiguchi N, et al. Role of inorganic polyphosphate in promoting ribosomal protein degradation by the Lon protease in E. coli. Science. 2001;293(5530):705-8.

49. Granato ET, Meiller-Legrand TA, Foster KR. The evolution and ecology of bacterial warfare. Curr Biol. 2019:29(11):R521-R37.

50. Chamot-Rooke J, Mikaty G, Malosse C, Soyer M, Dumont A, Gault J, et al. Posttranslational modification of pili upon cell contact triggers $N$. meningitidis dissemination. Science. 2011;331(6018):778-82.

51. Ellison CK, Dalia TN, Ceballos AV, Wang JCY, Biais N, Brun Y, et al. Retraction of DNA-bound type IV competence pili initiates DNA uptake during natural transformation in Vibrio cholerae. Nat Microbiol. 2018:3(7):773-80.

52. Craig L, Forest KT, Maier B. Type IV pili: dynamics, biophysics and functional consequences. Nat Rev Microbiol. 2019:17(7):429-40.

53. Ruhe ZC, Subramanian P, Song KH, Nguyen JY, Stevens TA, Low DA, et al. Programmed secretion arrest and receptor-triggered toxin export during antibacterial contact-dependent growth inhibition. Cell. 2018;175(4):921-33. 
54. Fernandez-Gomez B, Richter M, Schuler M, Pinhassi J, Acinas SG, Gonzalez $\mathrm{JM}$, et al. Ecology of marine Bacteroidetes: a comparative genomics approach. Isme J. 2013;7(5):1026-37.

55. Legrand TPRA, Catalano SR, Wos-Oxley ML, Fran S, Matt L, Bansemer MS, et al. The inner workings of the outer surface: skin and gill microbiota as indicators of changing gut health in yellowtail kingfish. Front Microbiol. 2018:8:2664

56. Mu D, Zhao J, Wang Z, Chen G, Du Z. Draft genome sequence of Algoriphagus sp. strain $\mathrm{NH1}$, a multidrug-resistant bacterium isolated from coastal sediments of the northern Yellow Sea in China. Genome Announc. 2016:4(1):e01555-15.

57. Qin QL, Xie BB, Zhang XY, Chen XL, Zhou BC, Zhou JZ, et al. A proposed genus boundary for the prokaryotes based on genomic insights. J Bacteriol. 2014;196(12):2210-5.

58. Mu DS, Yu XX, Xu ZX, Du ZJ, Chen GJ, et al. Sci Rep. 2016:6:srep29953.

59. Westermann AJ, Forstner KU, Amman F, Barquist L, Chao Y, Schulte LN, et al. Dual RNA-seq unveils noncoding RNA functions in host-pathogen interactions. Nature. 2016;529(7587):496-501.

60. Overbeek R, Olson R, Pusch GD, Olsen GJ, Davis JJ, Disz T, et al. The SEED and the rapid annotation of microbial genomes using subsystems technology (RAST). Nucleic Acids Res. 2014;42(D1):D206-D14.

61. Ellison CK, Kan J, Dillard RS, Kysela DT, Ducret A, Berne C, et al. Obstruction of pilus retraction stimulates bacterial surface sensing. Science. 2017; 358(6362):535-8

62. Rognes T, Flouri T, Nichols B, Quince C, Mahe F. VSEARCH: a versatile open source tool for metagenomics. Peerj. 2016:4:2584.

63. Stamatakis A. RAxML version 8: a tool for phylogenetic analysis and postanalysis of large phylogenies. Bioinformatics. 2014;30(9):1312-3.

64. Price MN, Dehal PS, Arkin AP. FastTree 2--approximately maximumlikelihood trees for large alignments. PLoS One. 2010;5(3):e9490.

65. Liu XB, Li M, Castelle CJ, Probst Al, Zhou ZC, Pan J, et al. Insights into the ecology, evolution, and metabolism of the widespread Woesearchaeotal lineages. Microbiome. 2018;6:102.

66. Na SI, Kim YO, Yoon SH, Ha SM, Baek I, Chun J. UBCG: up-to-date bacterial core gene set and pipeline for phylogenomic tree reconstruction. J Microbiol. 2018;56(4):280-5.

67. Yu GC, Smith DK, Zhu HC, Guan Y, Lam TTY. GGTREE: an R package for visualization and annotation of phylogenetic trees with their covariates and other associated data. Methods Ecol Evol. 2017;8(1):28-36.

\section{Publisher's Note}

Springer Nature remains neutral with regard to jurisdictional claims in published maps and institutional affiliations.

Ready to submit your research? Choose BMC and benefit from:

- fast, convenient online submission

- thorough peer review by experienced researchers in your field

- rapid publication on acceptance

- support for research data, including large and complex data types

- gold Open Access which fosters wider collaboration and increased citations

- maximum visibility for your research: over $100 \mathrm{M}$ website views per year

At BMC, research is always in progress.

Learn more biomedcentral.com/submissions 